\title{
Removal efficiency of nickel and lead from industrial wastewater using microbial desalination cell
}

\author{
Fariba Mirzaienia $^{1} \cdot$ Ali Asadipour $^{2} \cdot$ Ahmad Jonidi Jafari $^{3,4} \cdot$ Mohammad Malakootian $^{1,5}$
}

Received: 8 August 2016/Accepted: 18 November 2016/Published online: 28 November 2016

(C) The Author(s) 2016. This article is published with open access at Springerlink.com

\begin{abstract}
Microbial desalination cell (MDC) is a new method of desalination. Its energy is supplied through microbial metabolism of organic materials. In this study, synthetic samples were provided with concentration of 25 , 50, 75, $100 \mathrm{mg} / \mathrm{L} \mathrm{Ni}$ and $\mathrm{Pb}$. Removal efficiency of each metal was analyzed after 60, 90, 120 min, psychrophilic, mesophilic, thermophilic and $3-4,4-5,5-6 \mathrm{mg} / \mathrm{L}$ dissolved oxygen. Optimum conditions for removing $\mathrm{Ni}$ and $\mathrm{Pb}$ were achieved in $100,4.5$ and $4.6 \mathrm{mg} / \mathrm{L}$ dissolved oxygen, respectively, $26{ }^{\circ} \mathrm{C}$ and $120 \mathrm{~min}$. Nickel and led were removed from wastewaters of Isfahan electroplating industry and steel company. The maximum removal efficiencies of $\mathrm{Ni}$ and $\mathrm{Pb}$ in real samples were 68.81 and $70.04 \%$. MDC can be considered as a good choice for removing $\mathrm{Ni}$ and $\mathrm{Pb}$ from industrial wastewater. Due to microorganisms for decomposing organic material in municipal wastewater, metals from industrial wastewater can be removed simultaneously.
\end{abstract}

Mohammad Malakootian

m.malakootian@yahoo.com

1 Department of Environmental Health, School of Public Health, Kerman University of Medical Sciences, Kerman, Iran

2 Department of Medicinal Chemistry, Pharmaceutical Research Center, School of Pharmacy, Kerman University of Medical Sciences, Kerman, Iran

3 Center for Environmental Health Technology, School of Public Health, Iran University of Medical Sciences, Tehran, Iran

4 Department of Environmental Health Engineering, School of Public Health, Iran University of Medical Sciences, Tehran, Iran

5 Environmental Health Engineering Research Center, Kerman University of Medical Sciences, Kerman, Iran
Keywords Microbial desalination cell · Isfahan electroplating wastewater · Isfahan steel company wastewater

\section{Introduction}

Large volumes of wastewater with high pollution intensity are produced by different processes annually and they must comply with discharge regulations before being discharged into the environment (Min et al. 2005). Many ways, including conventional treatment systems, have been proposed for wastewater treatment, but this process requires high setup costs and energy consumption (Oh and Logan 2005, Ghangrekar and Shinde 2007). This shows that humans are dramatically energydependent (Liu et al. 2004; Logan 2004; Rabaey and Verstraete 2005; Lovley 2006; Mohan et al. 2007).

Chemical and physical processes are used for the removal of heavy metals from wastewater, such as ion exchange (IX), redox, precipitation, and ultrafiltration (Bitton 2004). Such methods include nickel (II) removal from industrial plating effluent by Fenton process (Malakootian et al. 2015), use of hybrid nanoparticles of Tio2/ Sio2 in removal of lead from paint industry effluents (Malakootian et al. 2012), and photocatalytic processes using silica and zirconia nanoparticles in the bivalent nickel removal of aqueous solutions and determining the optimum removal conditions (Malakootian and Cholicheh 2012).There is investigation of $\mathrm{Fe}_{3} \mathrm{O}_{4}$ nanoparticles modified with orange peel efficiency in removal of lead and copper ions from aqueous environments (Malakootian et al. 2014), $\mathrm{Pb}$ and Co removal from paint industries effluent using wood ash (Malakootian et al. 2008)were used for removing metals from industrial wastewater.

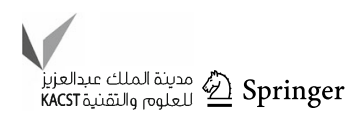


Sometimes, microorganisms obtain methods for separating and removing metals that can replace physical and chemical methods (Bitton 2004). For this reason, some studies have been carried out to collect renewable energy from organic waste sources and it is well known that microorganisms can produce fuels, such as ethanol, methane, hydrogen and electricity from organic materials (Shukla et al. 2004; Oh and Logan 2005; Kim et al. 2005; Liu et al. 2005; Logan and Regan 2006).

Microbial desalination cell (MDC) is a new method of desalination and its energy is supplied through microbial metabolism of organic materials. In other words, organic matter decomposition and energy production are conducted by microorganisms in water solution and chemical oxidation regardless of whether it is organic or inorganic substrate (Maier et al. 2000; Kim and Logan 2013; Brastad and He 2013). The first MDC that is proposed for desalination consists of three parts of anode, cathode and desalination chamber between the anode and the cathode (Cao et al. 2009).

In the anode, exoelectrogenic microorganisms oxidize organic materials. During the oxidation process, electrons are removed from the substrate and transferred to the terminal electron acceptor (TEA, i.e., cathode) from the electron transport chain. In the cathode, oxygen usually acts as the TEA. The reaction of these electrodes creates an electrical potential gradient (Maier et al. 2000, Kim and Logan 2013).

In the electric field created, anions are absorbed by the anode and cations are led to the cathode. Water desalination is done in the middle chamber by IX membranes. AEM and CEM are located after the anode and cathode, respectively (Kim and Logan 2013).

Exoelectrogenics is a feature that is granted to the bacteria. "Exo" means outside the cell and "electrogens" means the ability to transfer electrons to insoluble electron acceptors (Zuo et al. 2008).

The concept of MDC was first introduced by Cao et al. (2009) on a small scale (capacity of $3 \mathrm{~mL}$ of salt water) and later by Jacobson et al. with larger scale (approximately, 1 L salt water capacity) (Cao et al. 2009; Jacobson et al. 2011a, b). A Chinese study showed reduction of hexavalent chromium by MDC method by $75.1 \%$ (An et al. 2014).

In this study, the removal of nickel $(\mathrm{Ni})$ and lead $(\mathrm{Pb})$ was investigated by MDC method. Polyester fabrics such as AEM and CEM were used. In most other studies, Gel polystyrene has been used. Ion exchange capacity of AEM and CEM was 1.6 and $1.9 \mathrm{meq} / \mathrm{g}$. For swelling membranes, demineralized water instead of $\mathrm{NaCl}$ is used.

\section{Materials and methods}

\section{Materials and reagents}

Anion exchange membranes (fumasep FTAM-E) and cation exchange membranes (fumasep FTCM-E) were purchased from FuMA-Tech GmbH Company of Germany. Carbon graphite electrodes were purchased from Pariz Fan Company in Iran. All chemical materials, including phosphate buffer, nickel (II) chloride hexahydrate, lead (II) nitrate, sulfuric acid, sodium hydroxide were purchased from Merck.

\section{Analytical methods}

The quantity of removed metals in each sample was measured by atomic absorption spectrometric device (Younglin AAS 8020 manufactured by YL Instrument South Korea). The $\mathrm{pH}, \mathrm{EC}$ and turbidity were measured by $\mathrm{pH}$ meter, EC meter and turbid meter, respectively. Experiments, such as TSS, BOD and COD were performed in accordance with procedures noted in standard methods for examinations of water and wastewater $2540 \mathrm{D}, 5210$ and $5220 \mathrm{Cr}$. Sulfate, ammonia and volatile fatty acids (VFCs) were performed in accordance with $4500 \mathrm{D}, 4500 \mathrm{E}$ and $5560 \mathrm{C} . \mathrm{Cu}, \mathrm{Zn}$, $\mathrm{Cr}, \mathrm{Ni}, \mathrm{Cd}, \mathrm{Pb}$ and $\mathrm{Hg}$ were performed in accordance with $3111 \mathrm{~B}$ and $\mathrm{CN}$ were performed in accordance with 4500 D. (A.P.H.A. et al. 1999). SPSS, version 16 software was used for data analysis.

\section{Experimental procedure}

This experimental study was conducted on 108 synthetic samples containing $\mathrm{Ni}$ and 108 synthetic samples containing $\mathrm{Pb}$, and real samples containing $\mathrm{Ni}$ and $\mathrm{Pb}$ from wastewater of plating industries and Isfahan steel company.

First, a batch system reactor was built of Plexiglas with a thickness of $10 \mathrm{~mm}$ and outside dimensions of length, width and height were 48,18 and $18 \mathrm{~cm}$, respectively. Useful volume of MDC was about $8 \mathrm{~L}$. Included in the reactor was a bioelectrochemical chamber or anode and an electrochemical chamber or cathode with aerobic conditions and a middle chamber. Inside dimensions of the anode, cathode and middle chambers were each $14 \times 14 \times 14 \mathrm{~cm}^{3}$ and the volume of each of them was about 2.6 L. Inlet and outlet of all three chambers were located at the top and the bottom of each chamber, respectively.

These three chambers were separated by an anion exchange membrane (AEM) and a cation exchange membrane $(\mathrm{CEM})$ with dimensions of $18 \times 18 \mathrm{~cm}^{2}$. Then AEM 
was located between the anode chamber and the middle chamber, and the CEM between the middle chamber and the cathode chamber, and the membranes were soaked for $48 \mathrm{~h}$ in deionized water. To prevent membrane damage caused by the fluid pressure in chambers, the membrane was placed between two perforated backing Plexiglass plates.

The anode and cathode electrode made of carbon graphite were in the form of a rectangular cube with the dimensions of $4 \mathrm{~cm}$ length, $1 \mathrm{~cm}$ width and $14 \mathrm{~cm}$ height. The electrodes were connected to each other and then to a digital ohm meter device by copper wires. It should be noted that the electrodes were soaked in deionized water for $24 \mathrm{~h}$ before applying.

The anolyte in anode chamber included a return activated sludge from the Kerman wastewater treatment plants as a source of microorganisms, and municipal wastewater in aeration tanks as a source of organic matter. The catholyte in the cathode chamber included $0.1 \mathrm{M}$ phosphate buffer. The cathode chamber was aerated by aquarium aeration pump and the amount of dissolved oxygen (DO) was measured by a digital DO meter. The middle chamber included a synthetic sample containing $\mathrm{Ni}$ and $\mathrm{Pb}$ that were used from nickel (II) chloride hexahydrate and lead (II) nitrate, and its $\mathrm{pH}$ was set on 7 sing $0.1 \mathrm{M}$ sulfuric acid and $0.1 \mathrm{M}$ sodium hydroxide. The MDC pilot that was used during operation is shown in Fig. 1.

In Fig. 2a, b its performance and supporting plates are shown, respectively.

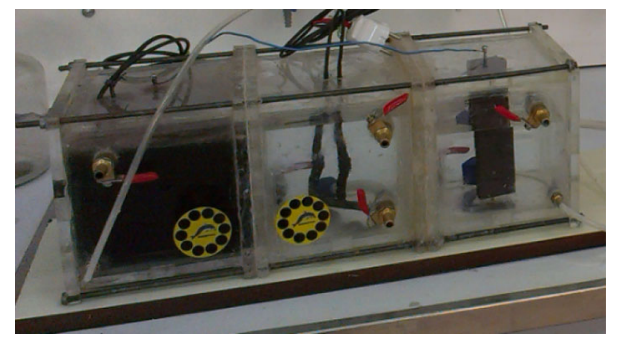

Fig. 1 MDC pilot
To study the removal efficiency, a $25 \mathrm{~mL}$ sample was taken from the outlet of the reactor in each case. Experiments for any of the tested concentrations of metals were conducted in the retention times of 60,90 and $120 \mathrm{~min}$ and at different psychrophile temperatures $\left(0-20{ }^{\circ} \mathrm{C}\right)$, mesophile $\left(20-35^{\circ} \mathrm{C}\right)$ and thermophile $\left(40-55^{\circ} \mathrm{C}\right)$ and the amount of DO in cathode chamber of $3-4,4-5$ and $5-6 \mathrm{mg} / \mathrm{L}$.

The results were read by a spectrophotometer atomic absorption device. Experiments were carried out under the same conditions on wastewater of Isfahan electroplating industry and wastewater of Isfahan steel company as real examples with determined quality. At the end, each metal removal rate was calculated from Eq. (1).

$\eta=\frac{C_{0}-C_{1}}{C_{0}} \times 100$

Where $\eta$ is the removal efficiency, $C_{0}$ and $C_{1}$ are the primary and secondary concentrations of metal. Data analysis was performed using descriptive statistics.

\section{Results}

\section{Dissolved oxygen and $\mathrm{Ni}$ and $\mathrm{Pb}$ removal}

The effect of $\mathrm{DO}$ on the removal of $\mathrm{Ni}$ and $\mathrm{Pb}$ in synthetic samples by MDC method is shown in Fig. 3.

Increased $\mathrm{DO}$ in the cathode chamber, $\mathrm{Ni}$ and $\mathrm{Pb}$ removal rate was initially increased and then decreased. Maximum efficiency of removal of $\mathrm{Ni}$ and $\mathrm{Pb}$, occurred in $4.4 \mathrm{mg} / \mathrm{L}$ DO. Removal rate of $\mathrm{Ni}$ and $\mathrm{Pb}$ in $3.46,5.44 \mathrm{mg} /$ $\mathrm{L}$ and $3.49,5.48 \mathrm{mg} / \mathrm{L}$ DO was decreased because the number of TEA in cathode chamber and nutrient in anode chamber was decreased, respectively.

\section{Retention time and $\mathrm{Ni}$ and $\mathrm{Pb}$ removal}

The effect of retention time on the removal of $\mathrm{Ni}$ and $\mathrm{Pb}$ in synthetic samples by MDC method is shown in Fig. 4.
Fig. 2 a The process of MDC: (1) oxygen bubbles; (2) cathode electrode (in cathode chamber); (3) CEM; (4) AEM; (5) heater; (6) exoelectrogenes bacteria; (7) anode electrode (in the anode chamber); (8) cations and anions. b AEM and CEM supporting plates (1) supporting (2) membrane

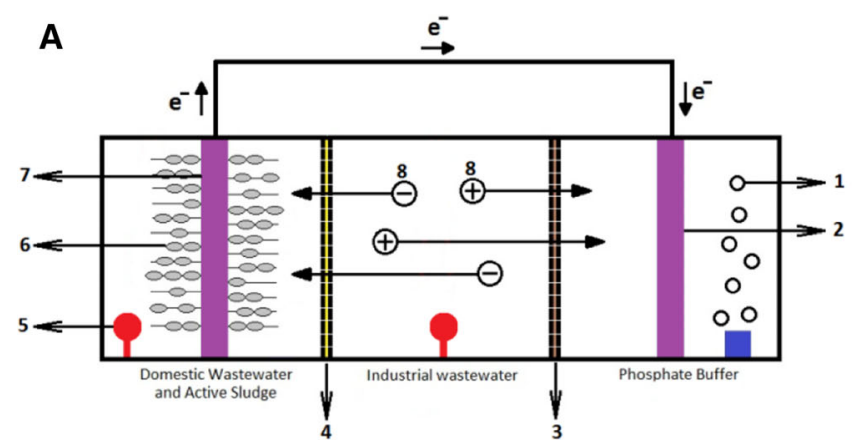

B

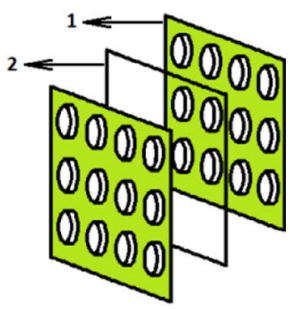


Fig. 3 The relationship between $\mathrm{DO}$ and removal of $\mathrm{Ni}$ and $\mathrm{Pb}$ by MDC method in synthetic sample

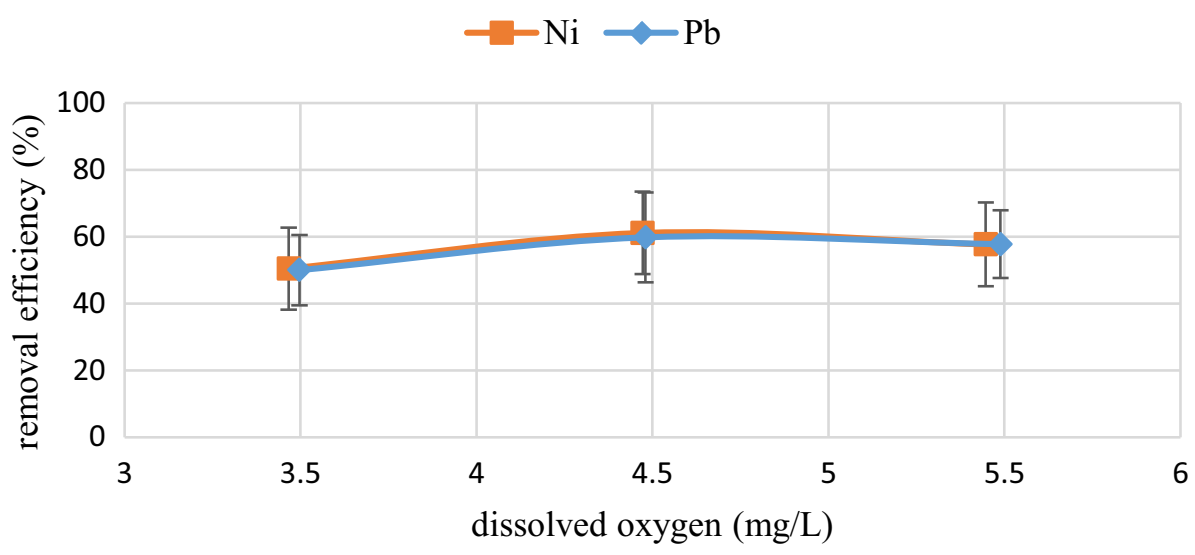

Fig. 4 The relationship between retention time and removal of $\mathrm{Ni}$ and $\mathrm{Pb}$ by $\mathrm{MDC}$ method in synthetic sample

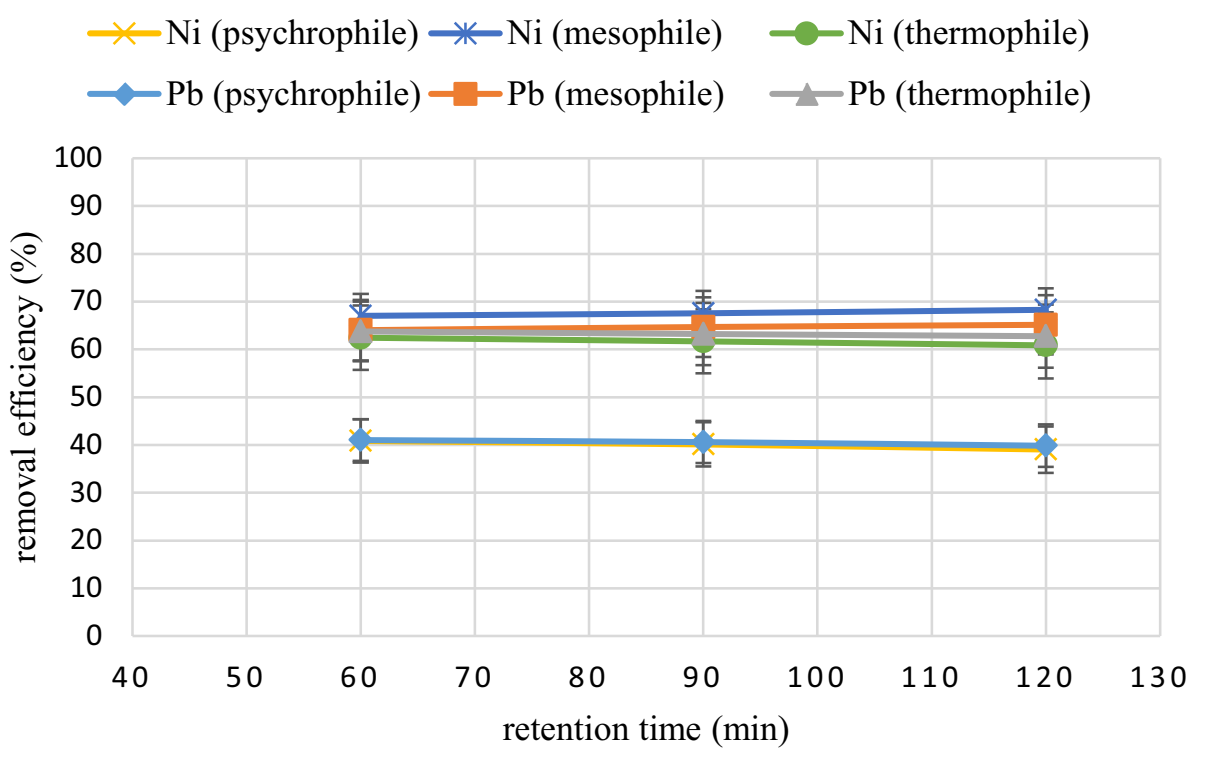

Increasing retention time in the psychrophile and thermophile phases decreased the removal of $\mathrm{Ni}$ and $\mathrm{Pb}$, and in the mesophile phase, the removal rate was increased because there were suitable conditions for microorganisms' metabolism.

\section{Temperature and $\mathrm{Ni}$ and $\mathrm{Pb}$ removal}

The effect of temperature on the removal of $\mathrm{Ni}$ and $\mathrm{Pb}$ in synthetic samples by MDC method is shown in Fig. 5.

As the temperature increases from psychrophile phase to mesophile phase, the removal of $\mathrm{Ni}$ and $\mathrm{Pb}$ was increased, and then it was decreased from mesophile phase to thermophile phase.

The temperature is one of the parameters affecting microbial growth and survival. Since the temperature inside a bacterial cell is similar to the temperature of the surrounding environment, increased environment temperature increases microbial activity to the point that rising temperatures will cause the loss of cells (Zazouli and
Bazrafshan 2009). Therefore, the voltage produced by exoelectrogenic bacteria during the removal of $\mathrm{Ni}$ and $\mathrm{Pb}$ by MDC method in psychrophile and thermophile phases is declined due to poor growing conditions and the removal of $\mathrm{Ni}$ and $\mathrm{Pb}$ are also declined.

\section{Concentration and $\mathrm{Ni}$ and $\mathrm{Pb}$ removal}

The effect of the concentration on the removal of $\mathrm{Ni}$ and $\mathrm{Pb}$ in synthetic samples by MDC method is shown in Fig. 6 .

A direct relationship was observed between concentration and removal of $\mathrm{Ni}$ and $\mathrm{Pb}$, and increasing concentration increased removal due to the presence of more ions in synthetic solution. Maximum efficiency of removal of $\mathrm{Ni}$ and $\mathrm{Pb}$ occurred in $120 \mathrm{mg} / \mathrm{L}$ concentration. Removal efficiency of $\mathrm{Pb}$ is more than $\mathrm{Ni}$, because electron capacity of $\mathrm{Pb}(4+)$ is more than $\mathrm{Ni}(3+)$.

According to the statistical analysis of the synthetic sample of $\mathrm{Ni}$ and $\mathrm{Pb}$, with 0.94 and 0.99 line slope, the maximum efficiency of removal of $\mathrm{Ni}$ and $\mathrm{Pb}$ in the 
Fig. 5 The relationship between temperature and removal of $\mathrm{Ni}$ and $\mathrm{Pb}$ by MDC method in synthetic sample
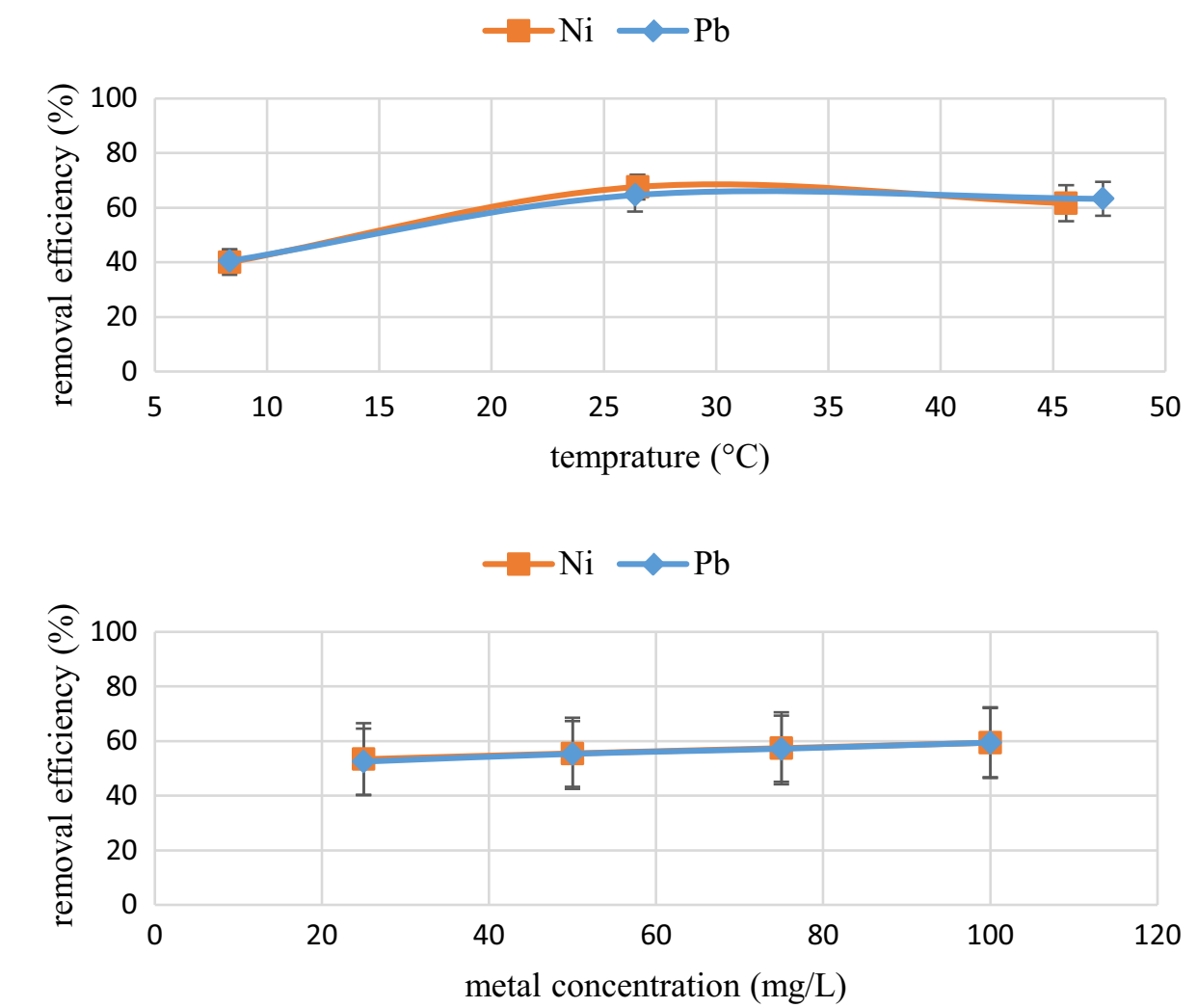

metal concentration $(\mathrm{mg} / \mathrm{L})$
Fig. 6 The relationship between concentration and removal of $\mathrm{Ni}$ and $\mathrm{Pb}$ by $\mathrm{MDC}$ method in synthetic sample

Table 1 Quality of wastewater of Isfahan electroplating industries

\begin{tabular}{|c|c|c|c|c|c|c|c|}
\hline$\overline{\mathrm{pH}}$ & $\mathrm{EC}(\mathrm{ds} / \mathrm{m})$ & & $\mathrm{ng} / \mathrm{L})$ & TSS (mg/L) & BOD $(\mathrm{mg} / \mathrm{L})$ & $\mathrm{COD}(\mathrm{mg} / \mathrm{L})$ & $\overline{\mathrm{SO}_{4}{ }^{2-}(\mathrm{mg} / \mathrm{L})}$ \\
\hline 6.1 & 14.8 & 90 & & 128 & 140 & 310 & 11.26 \\
\hline \multicolumn{2}{|c|}{$\mathrm{NH}_{4}^{+}(\mathrm{mg} / \mathrm{L})$} & VFC $(\mu \mathrm{g} / \mathrm{L})$ & $\mathrm{Cu}(\mathrm{mg} / \mathrm{L})$ & $\mathrm{Zn}(\mathrm{mg} / \mathrm{L})$ & $\mathrm{Cr}(\mathrm{mg} / \mathrm{L})$ & $\mathrm{Ni}(\mathrm{mg} / \mathrm{L})$ & $\mathrm{CN}(\mathrm{mg} / \mathrm{L})$ \\
\hline \multicolumn{2}{|l|}{2.91} & 422 & 14.22 & 3.85 & 14.51 & 24.43 & 0.012 \\
\hline
\end{tabular}

concentration of $100 \mathrm{mg} / \mathrm{L}$, and the DO of $4-5 \mathrm{mg} / \mathrm{L}$, at $20-35{ }^{\circ} \mathrm{C}$ and retention time of $120 \mathrm{~min}$ was 74.5 and $75.1 \%$, respectively. The highest voltage produced by the conditions listed above was 0.88 and $0.89 \mathrm{~V}$, respectively.

Electroplating is a common industry in Isfahan. Metals enter wastewater through washing and electroplating tanks. So if the process of electroplating is modified, metals cannot discharge in the wastewater. The quality of wastewater of Isfahan electroplating industries that was used as a real solution containing Ni was obtained as in Table 1.

Steel is a major industry in Isfahan. Wastewater types produced from this industry are domestic, industrial, salty and phenolic wastewater. We choose industrial wastewater because it contains heavy metals. The quality of wastewater of Isfahan steel company that was used as a real solution containing $\mathrm{Pb}$ was obtained as in Table 2 .

The results of applying optimal conditions on real samples are provided in Table 3.

\section{Discussion}

Malakootian et al. (2011) in Iran, in a study aimed at producing electricity through simulated food industry wastewater treatment using two-chamber MFCs and nafion membrane, concluded that the maximum voltage is produced in the oxygen concentration of 4-5 mg/L (Malakootian et al. 2011). Clauwert et al. (2007) in Australia, in a study entitled open air biocathode enables effective electricity generation with MFCs concluded that reducing DO in the cathode is one of the constraints of MFC (Clauwert et al. 2007). The listed studies are consistent with the results of this study because oxygen in the cathode chamber is as the terminal electron acceptor, and the depletion of DO, leads to reduced terminal acceptors and low electricity generation.

Luo et al. (2011) in the United States of America, in a study aimed at concurrent desalination and hydrogen 
Table 2 Quality of wastewater of Isfahan steel company

\begin{tabular}{|c|c|c|c|c|c|c|c|c|}
\hline $\mathrm{pH}$ & $\mathrm{EC}(\mathrm{ds}$ & $/ \mathrm{m})$ & Turbidity (mg/L) & $\begin{array}{l}\text { TSS } \\
(\mathrm{mg} / \mathrm{L})\end{array}$ & $\begin{array}{l}\text { BOD } \\
(\mathrm{mg} / \mathrm{L})\end{array}$ & $\begin{array}{l}\text { COD } \\
(\mathrm{mg} / \mathrm{L})\end{array}$ & $\mathrm{SO}_{4}{ }^{2-}(\mathrm{mg} / \mathrm{L})$ & $\mathrm{NH}_{4}^{+}(\mathrm{mg} / \mathrm{L})$ \\
\hline 7.4 & 20.7 & & 55 & 62 & 97 & 50 & 15.68 & 3.7 \\
\hline $\operatorname{VFC}(\mu \mathrm{g} / \mathrm{L})$ & & $\mathrm{Cu}(\mathrm{mg} / \mathrm{L})$ & $\mathrm{Zn}(\mathrm{mg} / \mathrm{L})$ & $\mathrm{Cd}(\mathrm{mg} / \mathrm{L})$ & $\mathrm{Pb}(\mathrm{mg} / \mathrm{L})$ & $\mathrm{Ni}(\mathrm{mg} / \mathrm{L})$ & $\mathrm{Hg}(\mathrm{mg} / \mathrm{L})$ & $\mathrm{Cr}(\mathrm{mg} / \mathrm{L})$ \\
\hline 481 & & 0.06 & 0.12 & 0.33 & 0.02 & 0.038 & 0.41 & 0.1 \\
\hline
\end{tabular}

Table 3 Removal of $\mathrm{Ni}$ and $\mathrm{Pb}$ and the voltage produced by the MDC in real samples

\begin{tabular}{llllll}
\hline Metal & DO $(4-5 \mathrm{mg} / \mathrm{L})$ & Temperature $\left(20-35^{\circ} \mathrm{C}\right)$ & Retention time $(\mathrm{min})$ & Removal amount $(\%)$ & Voltage $(V)$ \\
\hline $\mathrm{Ni}$ & 4.6 & 26 & 120 & 68.81 & 0.86 \\
$\mathrm{~Pb}$ & 4.5 & 26 & 120 & 70.04 & 0.84 \\
\hline
\end{tabular}

generation using microbial electrolysis and desalination cells found that increased retention time increases desalination (Luo et al. 2011). Jacobson et al. (2011a) in America, in a study with the aim of efficient salt removal in a continuously operated up flow MDC with an air cathode found that long retention time involves more ions in the flow production and increases ions removal (Jacobson et al. 2011a). The mentioned studies are consistent with this study due to the increased retention time and the removal of ions.

Werner et al. (2013) in Saudi Arabia, in a study with the aim of wastewater treatment, energy recovery and desalination using a forward osmosis membrane in an air-cathode microbial osmotic fuel cell found that removal efficiency increases at $30{ }^{\circ} \mathrm{C}$ (Werner et al. 2013). Lio et al. (2005) in Pennsylvania, in a study entitled power generation in FedBatch MFC as a function of ionic strength, temperature and reactor configuration concluded that reduced temperature results in decreased electricity production (Lio et al. 2005). The results of these studies are consistent with our study because lower temperature can slow metabolism and increased temperature speeds up metabolism, so bacteria grow faster and die quickly (MCkinney 2008).

Lio et al. (2005) in Pennsylvania, in a study entitled power generation in Fed-Batch MFC as a function of ionic strength, temperature and reactor configuration, and Brastad et al. (2013) in the United States of America, in a study aimed at water softening using MDC technology found that higher number of ions results in greater electrical conductivity (Lio et al. 2005, Brastad and He 2013). The results of these studies are consistent with this study due to increased number of ions and electricity generation caused to increasing removal.

Results of Brastad et al. (2013) in the United States of America, aimed at water softening using MDC technology are consistent with this study because lower electron capacity of the metal leads to reduced removal (Brastad and $\mathrm{He} 2013$ ).

Ammonia, sulfate and volatile fatty acids are common pollutant in industrial wastewater (Siles et al. 2010; Singhania et al. 2013; Zacharof and Lovitt 2013). There are some methods to recover them or resolve their inhibitor, such as recovery of ammonia and sulfate from waste streams and bioenergy production via bipolar bioelectrodialysis (Zhang and Angelidaki 2015c), submersible microbial desalination cell for simultaneous ammonia recovery and electricity production from anaerobic reactors containing high levels of ammonia (Zhang and Angelidaki 2015d), counteracting ammonia inhibition during anaerobic digestion by recovery using submersible microbial desalination cell (Zhang and Angelidaki 2015b), microbial electrochemical monitoring of volatile fatty acids during anaerobic digestion (Jin et al. 2016), and bioelectrochemical recovery of waste-derived volatile fatty acids and production of hydrogen and alkali (Zhang and Angelidaki 2015a).

In this MDC, at the top of the reactor, an anode chamber, there was a small hole for exiting gases such as ammonia that were produced during decomposition of organic materials.

\section{Conclusion}

Removal efficiencies of $\mathrm{Ni}$ from wastewater of Isfahan electroplating industry and $\mathrm{Pb}$ from wastewater of Isfahan steel company in optimum condition were 68.81 and $70.04 \%$. Optimum conditions for removing $\mathrm{Ni}$ and $\mathrm{Pb}$ from industrial wastewater were 4.6 and $4.52 \mathrm{mg} / \mathrm{L} \mathrm{DO}$, respectively, $26{ }^{\circ} \mathrm{C}$ and $120 \mathrm{~min}$ retention time for both. Advantages of MDC were the saving of energy, available exoelectrogenic bacteria and nutrient for them, 
simultaneous treatment for municipal and industrial wastewater. Thus, MDC is an effective method for removal of heavy metals, such as $\mathrm{Ni}$ and $\mathrm{Pb}$ present in industrial wastewater.

Acknowledgements This research was conducted at the Environmental Health Engineering Research Center and was sponsored by the Vice-Chancellor for Research and Technology of Kerman University of Medical Sciences. A note of appreciation is expressed here to the Vice-Chancellor and to all university staff who provided assistance to make this study possible.

Open Access This article is distributed under the terms of the Creative Commons Attribution 4.0 International License (http:// creativecommons.org/licenses/by/4.0/), which permits unrestricted use, distribution, and reproduction in any medium, provided you give appropriate credit to the original author(s) and the source, provide a link to the Creative Commons license, and indicate if changes were made.

\section{References}

A.P.H.A., A.W.W.A., W.P.C.F. (1999) Standard methods for the examination of water and wastewater. American Public Health Association

An Z, Zhang H, Wen Q, Chen Z, Du M (2014) Desalination combined with hexavalent chromium reduction in a microbial desalination cell. Desalination 354:181-188

Bitton G (2004) Wastewater microbiology. University of Tehran, Tehran

Brastad KS, He Z (2013) Water softening using microbial desalination cell technology. Desalination (New Directions in Desalination) 309:32-37

Cao X, Hung X et al. (2009) A new method for water desalination using microbial desalination cells. Environ Sci Technol 43:7148-7152

Clauwert P, Ha DVD, Boon N, Verbeken K, Verhaege M (2007) Open air biocathode enables effective electricity generation with microbial fuel cells. Environ Sci Technol 21:7564-7569

Ghangrekar MM, Shinde VB (2007) Performance of membrane-less microbial fuel cell treating wastewater and eVect of electrode distance and area on electricity production. Bioresour Technol 98:2879-2885

Jacobson KS, Drew DM, He Z (2011a) Efficient salt removal in a continuously operated upflow microbial desalination cell with an air cathode. Bioresour Technol 102:376-380

Jacobson KS, Drew DM, He Z (2011b) Use of a liter-scale microbial desalination cell as a platform to study bioelectrochemical desalination with salt solution or artificial seawater. Environ Sci Technol 45:4652-4657

Jin X, Angelidaki I, Zhang Y (2016) Microbial electrochemical monitoring of volatile fatty acids during anaerobic digestion. Environ Sci Technol 50:4422-4429

Kim Y, Logan BE (2013) Microbial desalination cells for energy production and desalination. Desalination (New Directions in Desalination) 308:122-130

Kim JR, Min B, Logan BE (2005) Evaluation of procedures to acclimate a microbial fuel cell for electricity production. Appl Microbiol Biotechnology 68:23-30. doi:10.1007/s00253-004-1845-6

Lio H, Cheng S, Logan BE (2005) Power generation in fed-batch microbial fuel cells as a function of ionic strength, temperature, and reactor configuration. Environ Sci Technol 39:5488-5493
Liu H, Ramnarayanan R, Logan BE (2004) Production of electricity during wastewater treatment using a single chamber microbial fuel cell. Environ Sci Technol 38:2281-2285

Liu H, Grot S, Logan BE (2005) Electrochemically assisted microbial production of hydrogen from acetate. Environ Sci Technol 39:4317-4320

Logan BE (2004) Feature article: biologically extracting energy from wastewater: biohydrogen production and microbial fuel cells. Environ Sci Technol 38:160-167

Logan BE, Regan JM (2006) Microbial challenges and fuel cell applications. Environ Sci Technol 40:172-180

Lovley DR (2006) Bug juice: harvesting electricity with microorganisms. Nat Rev Microbiol 4:497-508

Luo H, Jenkins PE, Ren Z (2011) Concurrent desalination and hydrogen generation using microbial electrolysis and desalination cells. Environ Sci Technol 45:340-344

Maier RM, Pepper LL, Gerba CP (2000) Environmental microbiology. Elsevier, Amsterdam

Malakootian M, Cholicheh MH (2012) Efficacy of photocatalytic processes using silica and zirconia nanoparticles in the bivalent nickel removal of aqueous solutions and determining the optimum removal conditions. J Mazandaran Univ Med Sci 93:87-96

Malakootian M, Almasi A, Hossaini H (2008) Pb and Co removal from paint industries effluent using wood ash. Int J Environ Sci Technol 5:217-222

Malakootian M, Amin MM, Mansoorian HJ, Haghighi NJ (2011) Electricity production through treatment of wastewater of protein food industry using dual chamber microbial fuel cell (MFC) with Nafion membrane and without intermediate and catalyst. Health Environ 4:385-400

Malakootian M, Kalankesh LR, Loloi M (2012) Efficiency of hybrid nano particles of Tio2/Sio2 in removal of lead from paint industry effluents. J Mazandaran Univ Med Sci 98:244-254

Malakootian M, Loloee M, Khazaee A (2014) Investigation of Fe3O4 nanoparticles modified with orange peel efficiency in removal of lead and copper ions from aqueous environments. Toloo Behdasht 2:1-11

Malakootian M, Yousefi N, Fatehizadeh A, Ginkel SWV, Ghorbani M, Rahimi S, Ahmadian M (2015) Nickel (II) removal from industrial plating effluent by fenton process. Environ Eng Manag J 14:837-842

MCkinney RE (2008) Environmental pollution control microbiology. Andishe Rafee

Min B, Kim J, Oh S et al. (2005) Electricity generation from swine wastewater using microbial fuel cells. Water Res 39:4961-4968

Mohan SV, Raghavulu SV, Srikanth S, Sarma PN (2007) Bioelectricity production by mediatorless microbial fuel cell under acidophilic condition using wastewater as substrate: influence of substrate loading rate. Curr Sci 92:1720-1726

Oh S, Logan BE (2005) Hydrogen and electricity production from a food processing wastewater using fermentation and microbial fuel cell technologies. Water Res 39:4673-4682

Rabaey K, Verstraete W (2005) Microbial fuel cells: novel biotechnology for energy generation. Trends Biotechnol 23:291-298

Shukla AK, Suresh P, Berchmans S, Rajendran A (2004) Biological fuel cells and their applications. Curr Sci 87:455-468

Siles JA, Brekelmans J, Martín MA, Chica AF, Martín A (2010) Impact of ammonia and sulphate concentration on thermophilic anaerobic digestion. Bioresour Technol 101:9040-9048

Singhania RR, Patel AK, Christophe G, Fontanille P, Larroche C (2013) Biological upgrading of volatile fatty acids, key intermediates for the valorization of biowaste through dark anaerobic fermentation. Bioresour Technol 145:166-174

Werner CM, Logan BE, Saikaly PE, Amy GL (2013) Wastewater treatment, energy recovery and desalination using a forward

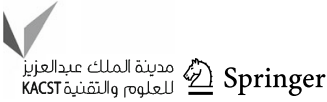


osmosis membrane in an air-cathode microbial osmotic fuel cell. Membr Sci 428:116-122

Zacharof M-P, Lovitt RW (2013) Complex effluent streams as a potential source of volatile fatty acids. Waste Biomass Valorization 4:557-581

Zazouli MA, Bazrafshan E (2009) Water and wastewater technology. Samat

Zhang Y, Angelidaki I (2015a) Bioelectrochemical recovery of wastederived volatile fatty acids and production of hydrogen and alkali. Water Res 81:188-195

Zhang Y, Angelidaki I (2015b) Counteracting ammonia inhibition during anaerobic digestion by recovery using submersible microbial desalination cell. Biotechnol Bioeng 112:1478-1482
Zhang Y, Angelidaki I (2015c) Recovery of ammonia and sulfate from waste streams and bioenergy production via bipolar bioelectrodialysis. Water Res 85:177-184

Zhang Y, Angelidaki I (2015d) Submersible microbial desalination cell for simultaneous ammonia recovery and electricity production from anaerobic reactors containing high levels of ammonia. Bioresour Technol 177:233-239

Zuo Y, Xing D, Regan JM, Logan BE (2008) Isolation of the exoelectrogenic bacterium Ochrobactrum anthropi YZ-1 by using a U-tube microbial fuel cell. Appl Environ Microbiol 74:3130-3137 